\title{
31. THE CHEMISTRY OF INTERSTITIAL WATERS, DEEP SEA DRILLING PROJECT LEG 86$^{1}$
}

\author{
Russell E. McDuff, University of Washington²
}

\begin{abstract}
Interstitial water samples from $\mathrm{Leg} 86$ were analyzed for $\mathrm{Cl}^{-}, \mathrm{SO}_{4}{ }^{2-}, \mathrm{Ca}^{2+}, \mathrm{Mg}^{2+}, \mathrm{K}^{+}, \mathrm{Li}^{+}, \mathrm{Sr}^{2+}, \mathrm{Mn}^{2+}, \mathrm{Si}_{\text {, }}$ $\mathrm{NO}_{3}{ }^{-}, \mathrm{NH}_{4}{ }^{+}$, and $\delta^{18} \mathrm{O}$. The principal findings are as follows. (1) The chloride profiles consistently show a $\sim 1.5 \%$ downcore increase to about $40 \mathrm{~m}$ sub-bottom depth. This increase is consistent with model profiles generated by considering the effects of variations in seawater salinity resulting from Pleistocene glaciation on pore-water composition. $\delta^{18} \mathrm{O}$ profiles support this model. This agreement of model and observation precludes advection of the pore fluids at rates greater than $1 \mathrm{~mm} / \mathrm{yr}$. (2) $\mathrm{Ca}^{2+}$ and $\mathrm{Mg}^{2+}$ gradients are small relative to other Deep Sea Drilling Project sites, likely resulting from low diffusive fluxes through underlying chert horizons. (3) Other constituents exhibit profiles consistent with previous observations.
\end{abstract}

\section{INTRODUCTION}

Under what conditions does advection of pore fluids in deep-sea sediments occur? Flow has been convincingly documented in young ridge-flank sediments by using various thermal and chemical tracers (Maris and Bender, 1982; Sayles and Jenkins, 1982). Anderson et al. (1979) proposed on the basis of thermal data that flow occurs even in very old sediments. The global distribution of chemical anomalies in Deep Sea Drilling Project (DSDP) cores is consistent with a model in which flow is active until the upper basalts are capped by a sufficient thickness $(\sim 100 \mathrm{~m})$ of relatively impermeable sediment (McDuff, 1981).

With the question of advection in mind, we analyzed pore fluids sampled during Leg 86 of DSDP in the northwest Pacific. We investigated the chemistry of the sediments at sites of similar crustal age but of varying sediment type and thickness, in order to refine the model of McDuff (1981). The geologic settings of the sites occupied are summarized in Table 1. All sites except Site 577 are below the carbonate-compensation depth (CCD) and consist mainly of pelagic clays, siliceous clays, and siliceous oozes (see Site chapters, this volume). Site 577 consists of nannofossil oozes. Sedimentation rates vary widely between the sites and increased with the onset of Pleistocene glaciation. Leg 86 samples were attractive for two other reasons. First, if flow occurs, one would expect rather small chemical anomalies because of the limited time available for chemical reaction to take place. It is difficult to document these small anomalies in rotary drill cores because of contamination by surface seawater, the drilling fluid. The samples from Leg 86 were collected with a hydraulic piston corer (HPC). Second, at Sites 576 and 578 , multiple complete sequences were cored by HPC. These sequences provided sufficient material to allow much more closely spaced sampling ( every $10 \mathrm{~m}$ )

\footnotetext{
${ }^{1}$ Heath, G. R., Burckle, L. H., et al., Init. Repts. DSDP, 86: Washington (U.S. Govt. Printing Office).

2 Address: School of Oceanography, University of Washington, Seattle, WA 98195.
}

than the 30- to 50-m spacing more typical in DSDP drill holes.

\section{METHODS}

Samples were collected aboard the Glomar Challenger during Leg 86 by expressing pore fluids in a Manheim-type stainless steel squeezer. No special precautions were taken with respect to temperature of squeezing artifacts (Sayles and Manheim, 1975). Three samples were taken at Site 576 with the Barnes in situ sampler; however, these samples were excessively contaminated with seawater and are not considered further.

Samples were analyzed aboard ship for alkalinity, $\mathrm{Cl}, \mathrm{Ca}, \mathrm{Mg}$, salinity, and $\mathrm{pH}$ following the standard protocol (see Introduction and Explanatory Notes, this volume). In our laboratory we repeated the analyses of $\mathrm{Cl}, \mathrm{Ca}$, and $\mathrm{Mg}$. In addition, we determined $\mathrm{K}, \mathrm{Li}, \mathrm{Sr}, \mathrm{Mn}$, $\mathrm{SO}_{4}{ }^{2-}, \mathrm{Si}, \mathrm{NO}_{3}{ }^{-}$, and $\mathrm{NH}_{4}{ }^{+}$and, for Sites 576 and $578, \delta^{18} \mathrm{O}$ of the water. The analytical methods used are summarized in Table 2 .

The method for chloride analysis requires some explanation. Chloride was determined by titration with $\mathrm{AgNO}_{3}$ with electrochemical endpoint detection. The electrochemical cell used was $\mathrm{Ag}, \mathrm{AgCl} \mid \mathrm{Ag}^{+}$ $\left|\mathrm{Ag}^{+}(0.165 \mathrm{M})\right| \mathrm{Ag}(\mathrm{s})$. The $\mathrm{Ag}, \mathrm{AgCl}$ electrode is placed in the sample and the $\mathrm{Ag}$ wire electrode is imbedded in the reservoir of a micrometer buret. The liquid junction is established across the buret tip, which is submersed in the sample, with $\mathrm{Ag}^{+}$controlled by the titrant strength on one side of the junction and by the progress of the titration on the other. The potential of the cell is balanced by means of a potentiometer. The course of the titration is followed in terms of $\Delta \mathrm{mV} / \Delta$ volume versus volume added. Control of quantities is the ultimate limit to precision; the $0.2-\mathrm{g}$ sample is gravimetrically controlled to $\pm 0.0001 \mathrm{~g}$ and the delivery of $\sim 0.7 \mathrm{ml}$ titrant is known to $\pm 0.0002 \mathrm{ml}$. Precisions of $\pm 0.05 \%(1 \sigma)$ are routinely obtained. The titer is determined by titration of IAPSO standard seawater.

The shipboard (Site chapters, this volume) and shore-based chloride and calcium determinations agreed within the precision of the methods employed. Our shore-based magnesium data are offset $+0.9 \%$ relative to the shipboard values, which have been converted to gravimetric units assuming a density of $1.022 \mathrm{~g} / \mathrm{cm}^{3}$. The reason for the offset is not readily apparent. The correction equations of Gieskes and Lawrence (1976) for reducing $\mathrm{Ca}$ and $\mathrm{Mg}$ data have not been applied to our data. The uncertainty in the correction is large for the small differences that exist in these samples relative to the composition of the standard. We found that for standards containing $46.0 \mathrm{mmol} / \mathrm{kg} \mathrm{Mg}$ and $15.0 \mathrm{mmol} / \mathrm{kg} \mathrm{Ca}$ we obtain better accuracy using the IAPSO titer than if we had applied the Gieskes and Lawrence correction. However, the correction is small relative to the observed offset and is of the wrong sign.

\section{RESULTS AND DISCUSSION}

Shore-based data are summarized in Table 3 and shown for Sites 576-580 in Figures 1-5. 
Table 1. Geologic settings, Leg 86 sites.

\begin{tabular}{|c|c|c|c|c|c|}
\hline Site & Location & $\begin{array}{l}\text { Water } \\
\text { depth } \\
\text { (m) }\end{array}$ & Sediments & $\begin{array}{c}\text { Pliocene-Pleistocene } \\
\text { sedimentation } \\
\text { rate } \\
(\mathrm{m} / \mathrm{m} . \mathrm{y} .)\end{array}$ & $\begin{array}{c}\text { Cenozoic } \\
\text { sedimentation } \\
\text { rate } \\
(\mathrm{m} / \mathrm{m} . \mathrm{y} .)\end{array}$ \\
\hline 576 & $\begin{array}{l}32^{\circ} 21.4^{\prime} \mathrm{N} \\
164^{\circ} 16.5^{\prime} \mathrm{E}\end{array}$ & 6217 & $\begin{array}{l}\text { Cenozoic pelagic clay } \\
\text { Cretaceous carbonate turbi- } \\
\quad \text { dite/pelagic clay }\end{array}$ & 7 & 0.9 \\
\hline 577 & $\begin{array}{l}32^{\circ} 26.5^{\prime} \mathrm{N} \\
157^{\circ} 43.4^{\prime} \mathrm{E}\end{array}$ & 2675 & $\begin{array}{l}\text { Cenozoic and Cretaceous } \\
\text { nannofossil ooze (Mio- } \\
\text { cene hiatus) }\end{array}$ & 13 & 1.8 \\
\hline 578 & $\begin{array}{l}33^{\circ} 55.6^{\prime} \mathrm{N} \\
151^{\circ} 37.7^{\prime} \mathrm{E}\end{array}$ & 6010 & $\begin{array}{l}\text { Pleistocene siliceous clay } \\
\text { Pliocene siliceous ooze, clay } \\
\text { Miocene clay } \\
\text { Paleogene pelagic clay }\end{array}$ & 27 & 3 \\
\hline 579 & $\begin{array}{l}38^{\circ} 37.7^{\prime} \mathrm{N}, \\
153^{\circ} 50.3^{\prime} \mathrm{E}\end{array}$ & 5737 & $\begin{array}{l}\text { Miocene-Pliocene-Pleistocene } \\
\text { siliceous clay and ooze, } \\
\text { with ash layers, pyrite } \\
\text { zones }\end{array}$ & 34 & Not reached \\
\hline 580 & $\begin{array}{l}41^{\circ} 37.5^{\prime} \mathrm{N} \\
153^{\circ} 56.6^{\prime} \mathrm{E}\end{array}$ & 5375 & $\begin{array}{l}\text { Pliocene-Pleistocene siliceous } \\
\text { clay and ooze }\end{array}$ & 48 & Not reached \\
\hline 581 & $\begin{array}{l}43^{\circ} 55.6^{\prime} \mathrm{N} \\
159^{\circ} 47.8^{\prime} \mathrm{E}\end{array}$ & 5476 & $\begin{array}{l}\text { Washed to } 181 \mathrm{~m} \\
\text { Pliocene-Miocene siliceous } \\
\text { clay and ooze overlying } \\
\text { chert } \\
\text { Basaltic basement at } 344 \mathrm{~m}\end{array}$ & 65 & 4 \\
\hline
\end{tabular}

Table 2. Methods used in Leg 86 interstitial water analyses.

\begin{tabular}{lll}
\hline Component & \multicolumn{1}{c}{ Method } \\
\hline $\mathrm{Cl}^{-}$ & Titration, electrometric end point & \multicolumn{1}{c}{ Reference } \\
$\mathrm{SO}_{4}{ }^{2-}$ & Titration & Gieskes, 1974 \\
$\mathrm{Ca}^{2+}$ & Titration & Gieskes and Lawrence, 1976 \\
$\mathrm{Mg}^{2+}$ & Titration & Gieskes and Lawrence, 1976 \\
$\mathrm{K}^{+}$ & Atomic absorption & Gieskes, 1974 \\
$\mathrm{Li}^{+}$ & Atomic absorption & Gieskes, 1974 \\
$\mathrm{Sr}^{2+}$ & Atomic absorption & Gieskes, 1974 \\
$\mathrm{Mn}^{2+}$ & Atomic absorption & Gieskes, 1974 \\
$\mathrm{Si}^{2}$ & Colorimetric & Mann and Gieskes, 1975 \\
$\mathrm{NO}_{3}^{-}$ & Colorimetric & Gardner et al., 1976 \\
$\mathrm{NH}_{4}^{+}$ & Colorimetric & Gieskes, 1974 \\
$\delta^{18} \mathrm{O}$ & Mass spectrometry & Epstein and Mayeda, 1953 \\
\hline
\end{tabular}

\section{Chloride}

\section{Background}

Chloride is normally thought of as a conservative constituent of the interstitial waters of marine sediments. Yet, beginning with the onset of distinct glacial-interglacial cycles in the late Pliocene-early Pleistocene, sea level has fluctuated considerably as a consequence of water storage in continental ice sheets. Concomitantly, mean seawater chlorinity must have changed, perhaps as much as $5 \%$ if one accepts the upper end of the range of estimated sea-level variations $(\sim 200 \mathrm{~m})$. How would such chloride fluctuations be recorded in deep-sea sediments?

\section{Model}

To model the potential influence of changes in deepwater chloride concentrations on interstitial-water profiles, we have adopted the following assumptions.

Assumption 1. The history of deep-water chlorinity can be represented by the pattern shown in Figure 6, which parallels the $\delta^{18} 0$ record and assumes chloride is $3.7 \%$ elevated at maximum glaciation.
Assumption 2. Initially (2 m.y. ago), chloride is constant with depth.

Assumption 3. Transport of chloride in the sediments is by diffusion alone.

Assumption 4. Chloride is considered to be unreactive in the sediment column.

With these assumptions, the mathematical model that follows is a simple one:

$$
\frac{\partial c}{\partial t}=D \frac{\partial^{2} c}{\partial z^{2}}
$$

subject to the initial condition:

$$
c(z, 0)=c_{0}
$$

and the boundary conditions:

$$
\begin{aligned}
& c(0, t)=f(t) \\
& c\left(z_{\mathrm{b}}, t\right)=c_{\mathrm{b}}
\end{aligned}
$$

where $c(z, t)$ is the chloride concentration, $t$ is time, $z$ is sub-bottom depth, and $f(t)$ is defined by Figure 6 . The depth $z_{b}$ corresponds to the depth of the sediment section and is taken as $200 \mathrm{~m}$ although any value will do as long as it is large relative to the depth to which the signal propagates. The parameter $c_{b}$, the concentration of chloride at the base of the sediment, is an additional variable as moderate increases in chloride are occasionally observed in drill cores, apparently supported by a flux from basaltic basement (McDuff, 1978). This set of equations is solved by a Crank-Nicholson scheme to yield chloride versus sub-bottom depth curves every 2000 yr. on a $10-\mathrm{m}$ grid.

Plots of chloride versus time at sub-bottom depths of 10,30 , and $60 \mathrm{~m}$ are shown in Figure 7 for a case with $c_{b}$ 
Table 3. Interstitial water data, Leg 86.

\begin{tabular}{|c|c|c|c|c|c|c|c|c|c|c|c|c|c|}
\hline $\begin{array}{c}\text { Sample } \\
\text { (interval in cm) }\end{array}$ & $\begin{array}{c}\text { Sub-bottom } \\
\text { depth (m) }\end{array}$ & $\underset{(\mathrm{mmol} / \mathrm{kg})}{\mathrm{K}^{+}}$ & $\underset{(\mathrm{mmol} / \mathrm{kg})}{\mathrm{Mg}^{2+}}$ & $\underset{(\mathrm{mmol} / \mathrm{kg})}{\mathrm{Ca}^{2+}}$ & $\begin{array}{c}\mathrm{Sr}^{2+} \\
(\mu \mathrm{mol} / \mathrm{kg})\end{array}$ & $\underset{(\mu \mathrm{mol} / \mathrm{kg})}{\mathrm{Li}^{+}}$ & $\underset{(\mu \mathrm{mol} / \mathrm{kg})}{\mathrm{Mn}^{2+}}$ & $\underset{(\mathrm{mmol} / \mathrm{kg})}{\mathrm{Cl}^{-}}$ & $\underset{(\mathrm{mmol} / \mathrm{kg})}{\mathrm{SO}_{4}^{2-}}$ & $\underset{(\mu \mathrm{mol} / \mathrm{kg})}{\mathrm{Si}}$ & $\underset{(\mu \mathrm{mol} / \mathrm{kg})}{\mathrm{NH}_{4}^{+}}$ & $\underset{(\mu \mathrm{mol} / \mathrm{kg})}{\mathrm{NO}_{3}^{-\mathrm{a}}}$ & $\begin{array}{l}{ }^{18} \mathrm{O} \\
(\% 0)\end{array}$ \\
\hline \multicolumn{14}{|l|}{ Site 576} \\
\hline $576 \mathrm{~A}-1-4,140-150$ & 6 & 11.3 & 51.57 & 10.22 & 90 & 28 & 52 & 540.4 & 28.9 & 450 & 5 & 55 & +0.13 \\
\hline $576 \mathrm{~A}-2-4,140-150$ & 15 & 12.0 & 51.90 & 10.35 & 90 & 32 & 30 & 541.7 & 28.0 & - & 0 & 44 & +0.26 \\
\hline $576 \mathrm{~A}-3-5,130-140$ & 26 & 11.6 & $\$ 1.44$ & 10.62 & 90 & 31 & 0 & 542.7 & 28.4 & 260 & 0 & 55 & +0.27 \\
\hline $576 \mathrm{~A}-4-4,140-150$ & 34 & 11.8 & 51.01 & 10.78 & 90 & 33 & 0 & 545.4 & 27.4 & 215 & 24 & 58 & +0.14 \\
\hline $576 \mathrm{~A}-5-4,140-150$ & 43 & 10.7 & 51.19 & 10.80 & 90 & 33 & 0 & 546.6 & 27.8 & 180 & 6 & 58 & +0.19 \\
\hline 576 A-6-5, $130-140$ & 54 & 12.4 & - & - & 90 & 37 & 2 & 543.9 & 26.0 & - & 0 & 60 & 0.00 \\
\hline $576 \mathrm{~A}-7-4,130-140$ & 62 & 11.6 & 51.59 & 10.60 & 90 & 37 & 0 & 539.8 & 27.1 & 190 & 3 & 52 & +0.05 \\
\hline Site 577 & & & & & & & & & & & & & \\
\hline $577-2-5,140-140$ & 14 & 12.5 & 51.94 & 9.79 & 115 & 25 & 11 & 543.9 & 29.1 & 185 & 26 & 3 & - \\
\hline $577-6-4,140-150$ & 50 & 11.8 & 52.27 & 10.38 & 155 & 23 & 3 & 545.6 & 27.7 & 200 & 27 & 8 & - \\
\hline $577-10-5,140-150$ & 90 & 10.0 & 53.06 & 10.45 & 125 & 22 & 0 & 541.9 & 27.3 & 155 & 0 & 11 & - \\
\hline $577 A-4-5,140-150$ & 36 & 11.9 & 52.35 & 9.97 & 125 & 22 & 3 & 544.6 & 27.5 & 195 & 27 & 4 & - \\
\hline $577 \mathrm{~A}-8-5,140-150$ & 74 & 10.0 & 52.90 & 10.80 & 145 & 22 & 0 & 543.0 & 27.7 & 205 & 20 & 3 & - \\
\hline $577 A-13-5,140-150$ & 121 & 10.1 & 52.06 & 10.78 & 135 & 25 & 0 & 540.2 & 27.3 & 225 & 0 & 0 & - \\
\hline \multicolumn{14}{|l|}{ Site 578} \\
\hline $578-2-5,140-150$ & 12 & 13.4 & 50.44 & 10.95 & 90 & 25 & 155 & 542.6 & 28.4 & 520 & 135 & 10 & +0.13 \\
\hline $578-5-6,140-150$ & 42 & 12.4 & 49.27 & 11.81 & 95 & 27 & 130 & 544.7 & 28.0 & 275 & 160 & 0 & +0.11 \\
\hline $578-8-5,140-150$ & 69 & 11.6 & 48.76 & 12.45 & 90 & 30 & 24 & 540.9 & 27.7 & 430 & 125 & 4 & - \\
\hline $578-11-6,140-150$ & 99 & 10.7 & - & - & 90 & 39 & 26 & 542.8 & 27.2 & 500 & 92 & 1 & -0.43 \\
\hline $578-14-3,140-150$ & 128 & 8.7 & 49.63 & 13.93 & 90 & 45 & 235 & 533.4 & 25.3 & 425 & 41 & 18 & -0.68 \\
\hline $578-17-3,140-150$ & 152 & 9.5 & 47.66 & 14.59 & 90 & 46 & 245 & 539.0 & 23.2 & 215 & 3 & 34 & -0.77 \\
\hline \multicolumn{14}{|l|}{ Site 579} \\
\hline $579-2-5,140-150$ & 16 & 12.4 & 51.05 & 10.58 & 90 & 27 & 135 & 545.6 & 27.0 & 290 & 160 & 5 & - \\
\hline $579 A-5-5,140-150$ & 59 & 11.3 & 49.55 & 11.31 & 90 & 44 & 110 & 551.2 & 25.9 & 410 & - & 0 & - \\
\hline $579 \mathrm{~A}-8-5,140-150$ & 88 & 12.2 & 48.50 & 11.74 & 95 & 53 & 110 & 547.6 & 25.2 & 470 & 265 & 13 & - \\
\hline $579 \mathrm{~A}-11-4,140-150$ & 115 & 12.2 & 47.80 & 12.08 & 90 & 63 & 92 & 550.2 & 24.9 & 425 & 275 & 9 & - \\
\hline $579 \mathrm{~A}-14-4,140-150$ & 143 & 11.1 & 47.64 & 12.44 & 90 & 71 & 120 & 548.3 & 24.1 & 535 & 225 & 6 & - \\
\hline \multicolumn{14}{|l|}{ Site 580} \\
\hline $580-2-5,140-150$ & 11 & 13.2 & 50.39 & 10.40 & 90 & 27 & 200 & 540.4 & 27.0 & 335 & 200 & 7 & - \\
\hline $580-5-5,140-150$ & 39 & 13.0 & 48.73 & 10.84 & 90 & 30 & 120 & $\$ 46.1$ & 24.9 & 385 & 395 & 6 & - \\
\hline $580-8-5,140-150$ & 68 & 12.3 & 47.82 & 11.06 & 90 & 35 & 97 & 547.0 & 23.8 & 595 & 475 & 8 & - \\
\hline $580-11-4,140-150$ & 95 & 11.9 & 46.45 & 11.42 & 90 & 41 & 93 & 549.0 & 22.4 & 485 & 525 & 4 & - \\
\hline $580-14-5,140-150$ & 124 & 11.8 & 46.61 & 11.65 & 95 & 49 & 87 & 546.1 & 22.3 & 500 & 530 & 7 & - \\
\hline $580-17-5,140-150$ & 153 & 11.7 & 45,42 & 11.80 & 90 & 63 & 77 & 546.1 & 21. & 540 & 515 & 11 & - \\
\hline \multicolumn{14}{|l|}{ Site 581} \\
\hline $581-5-3,140-150$ & 214 & 12.0 & 47.58 & 11.48 & 90 & 60 & 81 & 545.3 & 23.9 & 670 & 275 & 16 & - \\
\hline $581-8-4,140-150$ & 244 & 10.3 & 48.30 & 11.58 & 90 & 68 & 180 & 542.1 & 22.9 & 725 & 160 & 10 & - \\
\hline
\end{tabular}

Note: - means not determined.

a $\mathrm{NO}_{3}^{-}$determinations when $\mathrm{NH}_{4}^{+}$is appreciable are considered unreliable.

set to the present interglacial chloride concentration. Three regimes are evident. Near the sediment surface $(10 \mathrm{~m})$, the forcing function is quite obvious. At intermediate depths $(30 \mathrm{~m})$, the concentration is dampened somewhat and has achieved a value near the mean of the forcing function. At greater depth $(60 \mathrm{~m})$, the concentration is considerably dampened and has a value somewhat below the mean value of the forcing function, that is, the signal has just begun to arrive.

Thus, in a present-day profile, one would expect to find a maximum at about $30 \mathrm{~m}$ depth (Fig. 8). Also shown are cases in which $c_{b}$ has been increased and decreased $10 \%$. With $c_{b}$ increased, at present chloride is predicted to increase monotonically with depth. With $c_{b}$ decreased, a subsurface maxium is still predicted; however, the shift relative to bottom water is smaller than in the case with $c_{b}$ at the present interglacial chloride concentration.

I emphasize here that, although the signal is caused by glacial-interglacial cycles, it is not stratigraphic. Rather, it has penetrated from the sediment/water interface to a depth characteristic of a diffusive process acting over $\sim 1 \mathrm{~m} . \mathrm{y}$.

\section{Observations}

The Leg 86 chloride data, normalized to the presentday sediment/seawater interfacial values, are shown in Figure 9 . The pattern predicted by the model is evident. Chloride increases by about $1.5 \%$ by $40 \mathrm{~m}$ depth. Below that depth the concentration levels are variable, consistent with various $c_{b}$ values.

Isotopic data confirm that this agreement is the result of glacial-interglacial phenomena. Profiles of $\delta^{18} \mathrm{O}$ of the pore fluids at Sites 576 and 578 are shown in Figure 10. A maxium is apparent in both profiles. It is somewhat attenuated at Site 578. This attenuation is caused by the gradient of $\delta^{18} \mathrm{O}$ supporting a flux toward basement (Lawrence and Gieskes, 1981), analogous to the low chloride case shown in Figure 8.

\section{Pore-Water Migration}

Steady pore-water movement should displace the peak. Some model curves incorporating an advective term in Equation 1 are shown in Figure 11. The position of the peak is sensitive to velocities on the order of $0.1 \mathrm{~mm} /$ yr., and the existence of the signal at Leg 86 sites sug- 

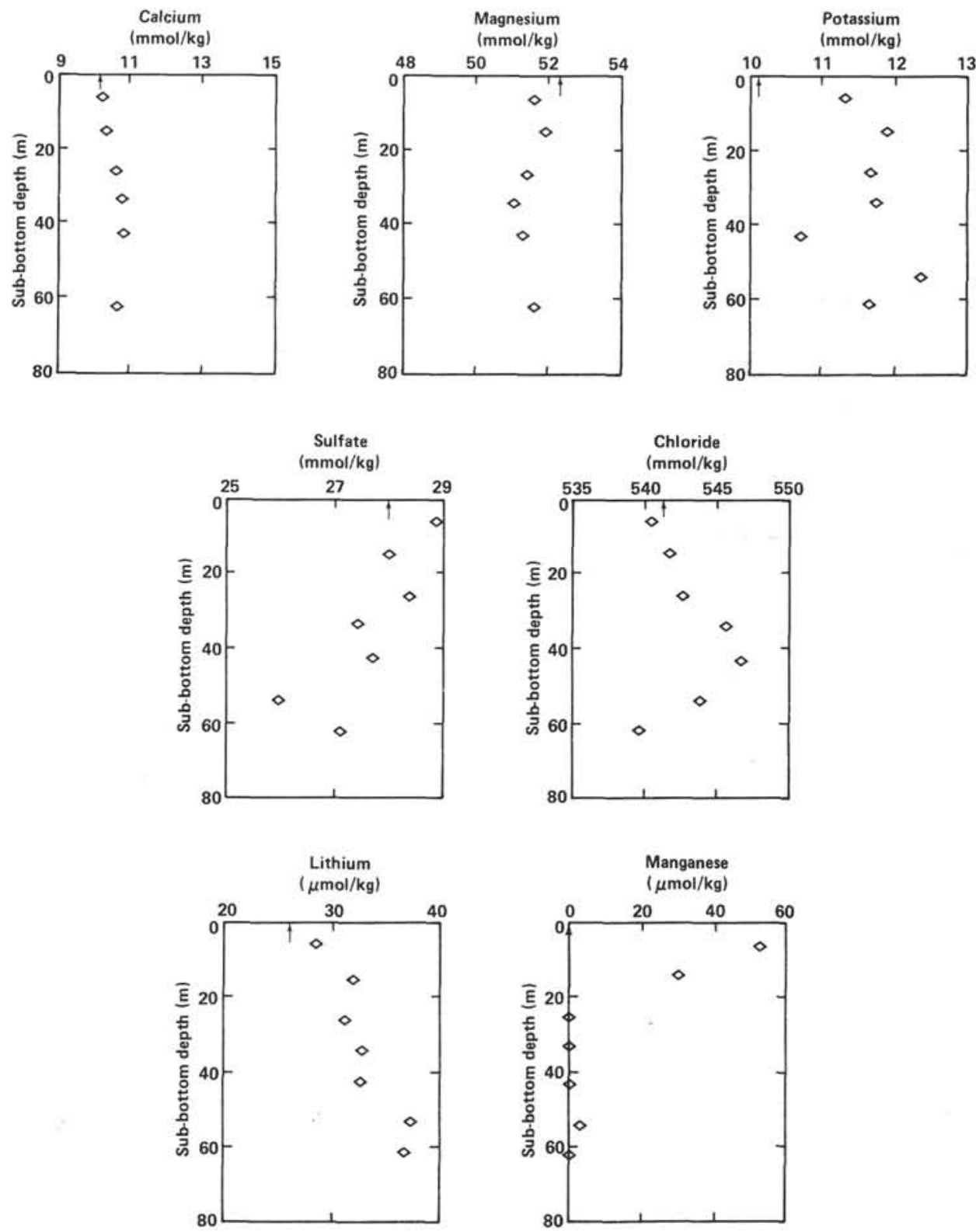

Figure 1. Interstitial water data, Site 576. Arrows indicate bottom-water concentration.

gests that advection must be occurring at rates certainly less than on the order of $1.0 \mathrm{~mm} / \mathrm{yr}$.

\section{Historic Data}

It is difficult to tell whether other existing DSDP data show the same feature, since most data sets include low-precision chloride determinations and sampling depths are generally widely spaced. One approach is to construct a composite profile. This has been done for the subset of sites identified by McDuff (1981) as having gradients of calcium and magnesium indicative of no fluid advection. Figure 12 shows the data displayed in two forms. The primary data (Fig. 12A) appear at first glance to form a shotgun pattern. However, averages over various depth intervals (Fig. 12B) show a distinct pat- tern, which we interpret in the following way. From the sediment/water interface to about $40 \mathrm{~m}$ depth there is a clear increase in the mean value. Note the very tight standard deviation in the 20 - to $40-\mathrm{m}$ depth interval and that no value between 20 and $40 \mathrm{~m}$ falls within $1 \%$ of present-day bottom water. Below this depth the mean remains about constant, however, the standard deviations generally increase. This is consistent with inclusions of sites with a flux from basement of chloride; that is, a profile of the mean less standard deviation corresponds to the no basement flux case (Fig. 8) and a profile of the mean plus the standard deviation corresponds to the basement flux case (Fig. 8). A similar result is found for $\delta^{18} \mathrm{O}$ (Fig. 13), although the subset of sites considered is different (those included in table 1 of Lawrence and Gies- 

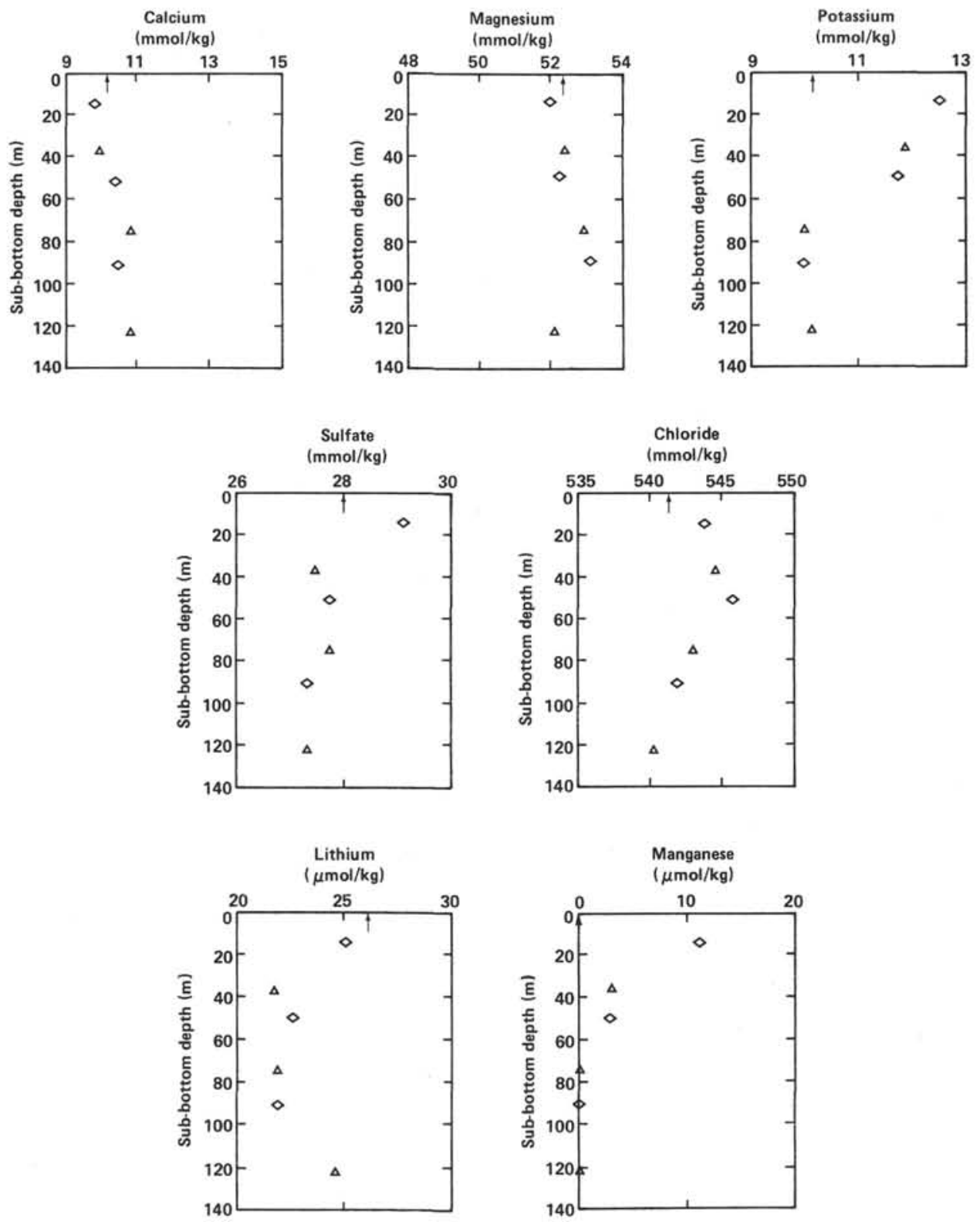

Figure 2. Interstitial water data, Site 577. Symbols: diamond $=$ Hole 577, triangle $=$ Hole 577A. Arrows indicate bottom-water concentration.

kes, 1981). A more comprehensive synthesis, including the implications for excess ice volume- $\delta^{18} \mathrm{O}$ coupling, is being prepared.

\section{Calcium and Magnesium}

The gradients of calcium and magnesium encountered during Leg 86 are small relative to the range observed in DSDP cores. Site 578 exhibits the largest value, $\sim 0.03$ $\mathrm{mmol} / \mathrm{m}$, which can be contrasted with gradients as high as $0.2 \mathrm{mmol} / \mathrm{m}$ at other DSDP sites (McDuff, 1981).

Changes in the concentrations of calcium and magnesium with sub-bottom depth are generally indicative of reaction of volcanic material, either basement basalts or volcanic ash that is dispersed within the sediment column (Gieskes and Lawrence, 1981; McDuff, 1981). At the three sites with measurable gradients (Sites 578-580,
Site 581 is excluded because of lack of data), $\mathrm{Ca}$ and $\mathrm{Mg}$ are linearly correlated, a feature usually resulting from conservative behavior of calcium and magnesium within the sediment column and gradients supported by diffusive fluxes from Layer 2 (McDuff and Gieskes, 1976; McDuff, 1978).

McDuff (1981) has presented a model for control of $\mathrm{Ca}$ and $\mathrm{Mg}$ gradients. To summarize, $\mathrm{Ca}$ is added to and $\mathrm{Mg}$ removed from the pore fluids of the basalts of Layer 2 by chemical reaction and lost or gained, respectively, by exchange with seawater. The thickness of sediment accumulated is critical in determining the mechanism of this exchange. One regime is characterized by thin sediment cover and lack of a Ca gradient. Two possible mechanisms can be imagined. One, previously presented, is that circulation of seawater through the sediment con- 

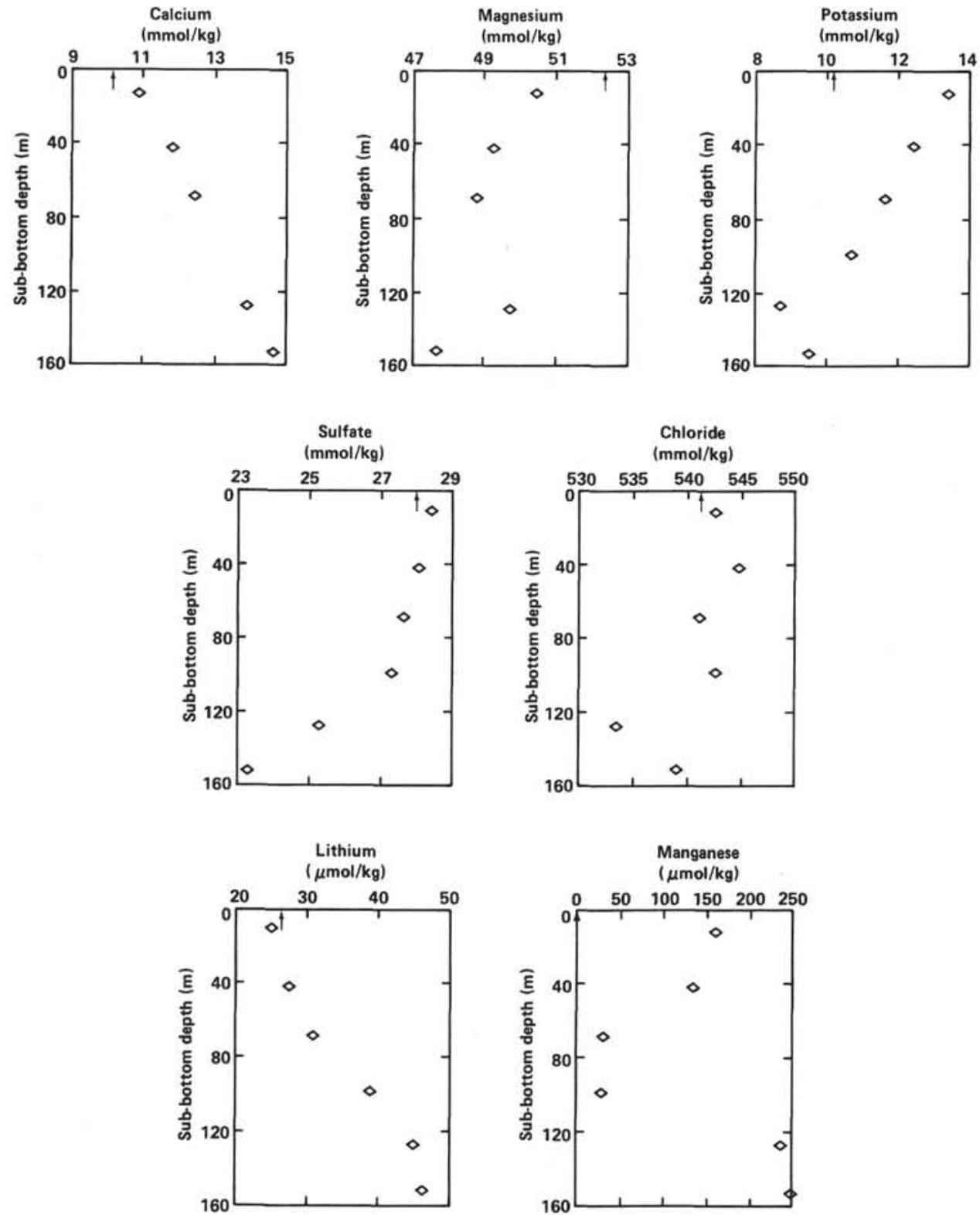

Figure 3. Interstitial water data, Site 578. Arrows indicate bottom-water concentration.

tinues at rates sufficient to obliterate gradients. There is strong evidence that this occurs in very thin sediment sections (Maris and Bender, 1982; Sayles and Jenkins, 1982). Although a moderately thin sediment cover may be sufficiently impermeable to stop fluid movement, another possible mechanism is that Layer 2 pore fluids may continue to be exchanged with seawater at basement outcrops. The profile of $\mathrm{Ca}$ in the sediment pore waters would then be controlled by diffusion between two seawater-dominated end members. The other regime is characterized by thicker sediments and the presence of $\mathrm{Ca}$ gradients. Transport through the sediment column is by diffusion (McDuff and Gieskes, 1976). Oxygen-isotope mass balances (Lawrence and Gieskes, 1981) and physical factors (McDuff, 1981) suggest that convection within Layer 2 continues to support these diffusive fluxes.

Some aspects of Leg 86 results are difficult to interpret within this framework. Relevant parameters are sum- marized in Table 4. Drilling generally penetrated a small fraction of the sediment cover inferred from seismic results, with the exception of Site 579 . The seismic results commonly contain evidence of chert horizons, sampled at several of the sites. The very low rate of diffusion of solutes through these horizons makes meaningful comparison of the observed fluxes to DSDP sites difficult. To some extent the concentration of solute in deeper layers will increase in response to the reduced transport through chert horizons stabilizing the flux; however, solubility prevents this concentration feedback from occurring on a compensating basis. The net result is a lower gradient in the upper sediments relative to sites without silicification. A good example of this phenomenon is the Ca profile at Site 356 (McDuff, 1978).

The chemistry observed at Leg 86 sites is quite similar to that of other DSDP sites. Figure 14 shows the values of $\Delta \mathrm{Ca} / \Delta \mathrm{Mg}$ as a function of the $\mathrm{Ca}$ gradient and, for 

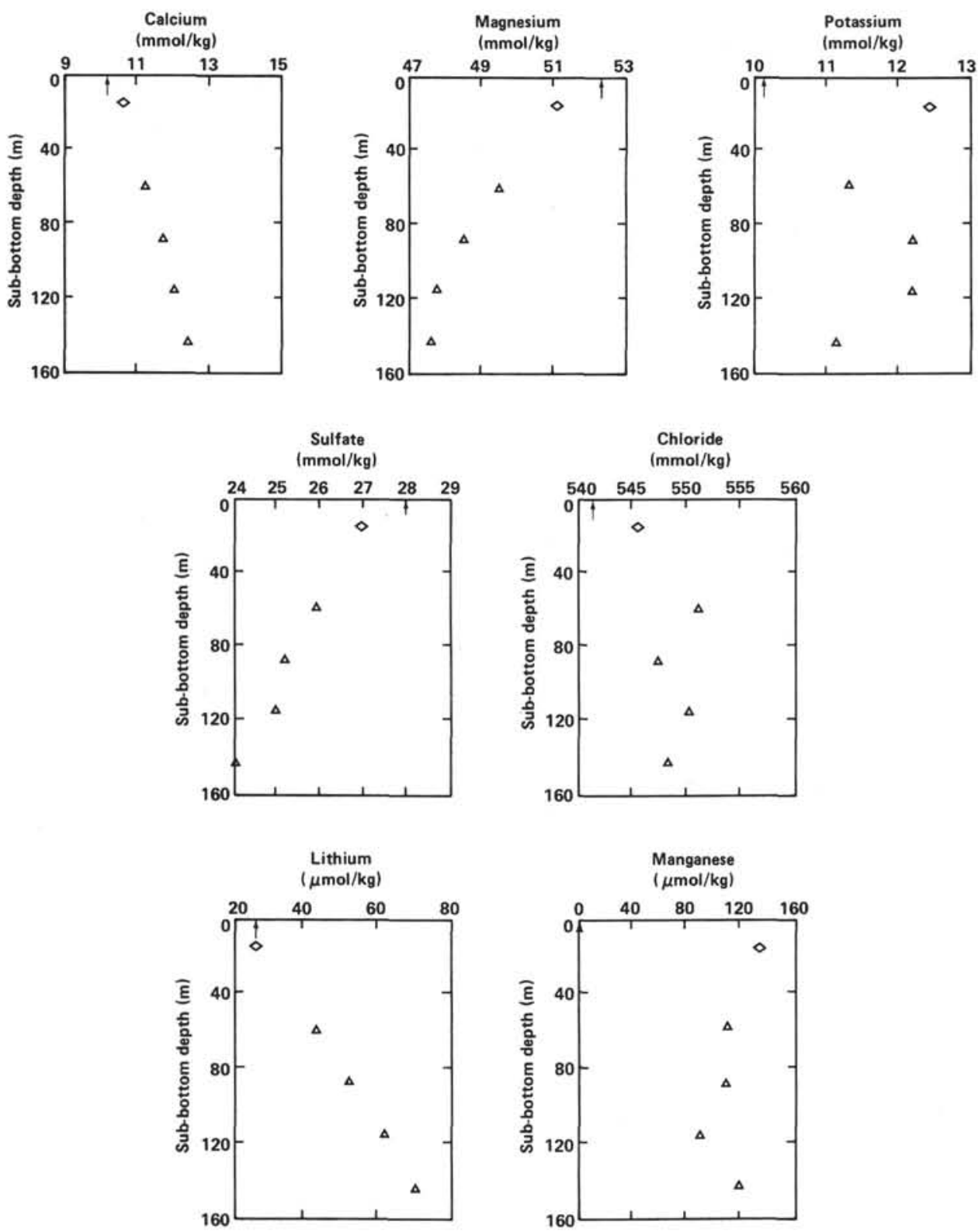

Figure 4. Interstitial water data, Site 579. Symbols: diamond $=$ Hole 579, triangle $=$ Hole 579A. Arrows indicate bottom-water concentration.

comparison, the linear relation found for Legs 1-53 (McDuff, 1981). At the extremely low fluxes characteristic of Leg 86 sites, $\mathrm{Ca}$ increases are much smaller than $\mathrm{Mg}$ decreases. This is consistent with the concept that, at low rates of basalt hydrolysis, magnesium must be supplied to counterbalance release of both excess calcium and sodium (McDuff, 1981).

\section{Redox Species}

The discussion of redox species is necessarily limited since shipboard participation would be required to produce reliable data for the full suite of important redox species. Our results include measurement of $\mathrm{NO}_{3}{ }^{-}$, $\mathrm{NH}_{4}{ }^{+}, \mathrm{Mn}^{2+}$, and $\mathrm{SO}_{4}{ }^{2-}$. Some artifacts may be introduced by analyzing for $\mathrm{NO}_{3}{ }^{-}$and $\mathrm{NH}_{4}{ }^{+}$approximately $1 \mathrm{yr}$. after sample collection. There is no visual evidence for extensive biological uptake in the samples; however, some bacterial oxidation of $\mathrm{NH}_{4}{ }^{+}$present at several hundred micromoles per kilogram in many of the samples is the probable source of non-zero $\mathrm{NO}_{3}{ }^{-}$determinations.

Recently there has been much progress in understanding the sequence of redox reactions that occurs in the upper tens of centimeters of marine sediments (Froelich et al., 1979; Jahnke et al., 1982). This sequence is driven by the relatively constant flux of organic carbon to the sediments. Generally the utilization of terminal electron acceptors follows the order of free energy that can be derived, that is $\mathrm{O}_{2}$ before $\mathrm{NO}_{3}{ }^{-}$, before or concurrent with $\mathrm{MnO}_{2}$, before $\mathrm{FeOOH}$, before $\mathrm{SO}_{4}{ }^{2-}$, before $\mathrm{CO}_{2}$. At high sedimentation rates, the complete sequence can be found in a short core, whereas at lower sedimentation rates $\mathrm{O}_{2}$ may be present even to the base of the sam- 

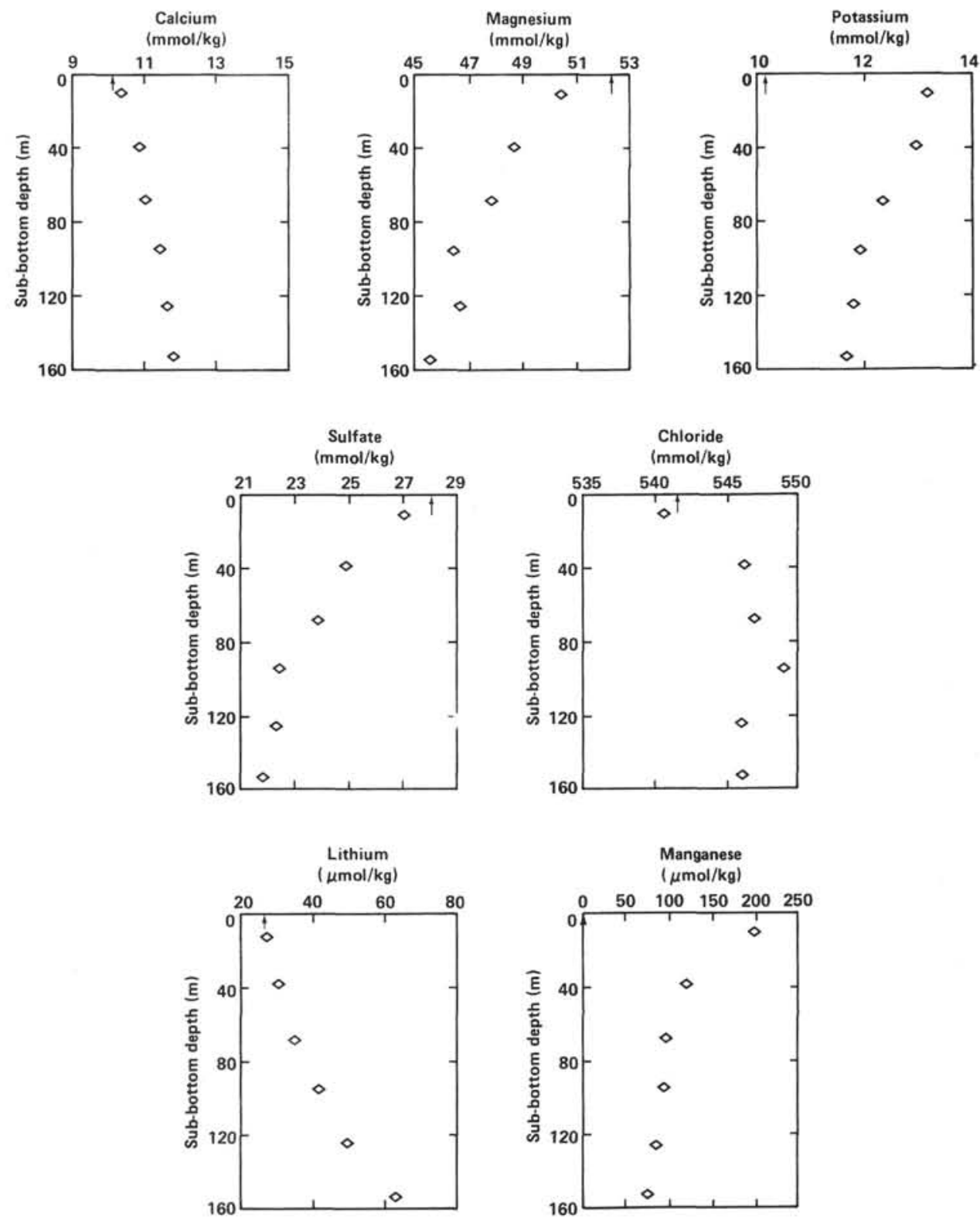

Figure 5. Interstitial water data, Site 580. Arrows indicate bottom-water concentration.

pled interval. In cores of similar sedimentation rate, secondary processes such as bioturbation can play an important role (Emerson et al., 1985).

The rate of sedimentation, and proportionally the supply of organic material, varies significantly in drill cores. Accordingly, while this sequence of utilization will be followed at a particular horizon, historic variations in sedimentation rate will influence the level within the sequence attained. At most Leg 86 sites, sedimentation has increased dramatically in Pliocene-Pleistocene times, as indicated in Table 1. Thus, one would expect the greatest progress through the sequence in the youngest sediments. An additional factor in older sediments is diffusion from either above or below, which may modify the signal. Other factors may also be of importance, especially for manganese. Gieskes (1981) noted a dissolved manganese-dissolved silica correlation which he attrib- utes to either association of Mn-oxides with siliceous material or availability of organic carbon in siliceous horizons. Boyle (1983) discussed the role of carbonate coatings in Mn cycling, especially in immobilizing $\mathrm{Mn}^{2+}$ released during suboxic diagenesis.

Most features of the Leg 86 results can be understood in the above context. (1) $\mathrm{NO}_{3}{ }^{-}$is enriched relative to bottom seawater in Site 576 sediments, a sign of oxic diagenesis and consistent with the slow rate of sedimentation. At all other sites $\mathrm{NO}_{3}-$ is depleted in the uppermost sediments. Because of the high $\mathrm{NH}_{4}{ }^{+}$concentration at deeper levels, it would be hazardous to assign significance to other results except to note that concentrations are probably very low in situ. (2) $\mathrm{Mn}^{2+}$ is strongly enriched in the upper sediments at all sites except Site 577. This is consistent with the suggestion of Boyle (1983) that carbonates can serve to immobilize $\mathrm{Mn}^{2+}$. At deeper 


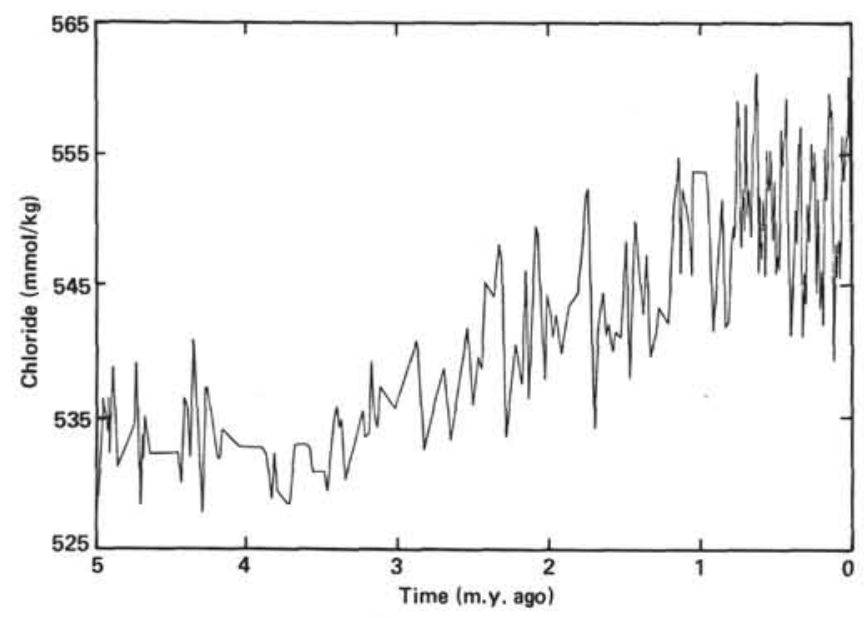

Figure 6. Chloride as a function of time used in model calculations. The curve parallels $\delta^{18} \mathrm{O}$ as a function of time assuming that chloride is elevated $3.7 \%$ at maximum glaciation $(\sim 150 \mathrm{~m}$ of sea-level change). The $\delta^{18} \mathrm{O}$ record used is a composite of the smoothed stacked record of SPECMAP (Imbrie et al., 1984) for the interval $0-0.8 \mathrm{~m} . \mathrm{y}$. ago and the measurements of Shackleton and Cita (1979) for the interval 5.0-0.8 m.y. ago. The Shackleton and Cita measurements have been converted to the standard deviation scale using the mean and standard deviation of their measurements in the interval 0-0.8 m.y. ago and have been interpolated between points to give a spacing of $2000 \mathrm{yr}$. No correction has been made for possible bottom-water temperature differences, which may be significant in the early parts of the record. These will have little effect on the computed chloride profiles, however.

levels $\mathrm{Mn}^{2+}$ enrichment is generally lower or absent, the exception being the substantial increase in $\mathrm{Mn}^{2+}$ concentration at the base of Site 578. Note at this horizon the very sharp gradient of sulfate. There are few data to support the Mn-Si association noted by Gieskes (1981). For example, at Site 578 the lowest $\mathrm{Mn}^{2+}$ concentrations occur at the level with the highest $\mathrm{Si}$ concentrations. (3) The $\mathrm{SO}_{4}{ }^{2-}$ profiles are unremarkable. Gradients are generally steeper at sites with higher sedimentation rates. An interesting feature appears in the sulfate profiles at Sites 576 and 577 . The sedimentation rate is lowest at these two sites. Sulfate values at both sites are in excess of bottom water in the uppermost sample. This may represent the same kind of effect as seen in the chloride data, recognizing that the diffusivity of sulfate is much lower so that the maximum is found closer to the sediment/water interface and will decay more slowly from the latest influence of glacial conditions. This requires conservative behavior of sulfate in these shallow sediments, consistent with the low sedimentation rate.

\section{Other Constituents}

\section{Strontium}

Only carbonate-bearing sediments from Site 577 exhibit a gradient of $\mathrm{Sr}$, reaching a maximum value $\sim 1.8 \times$ seawater at $50 \mathrm{~m}$ depth. This shallow maximum does not conform to the models of Gieskes (1981) and Baker et al. (1982). First, the maximum occurs nearly a factor of ten shallower than the communication length (ratio diffusion coefficient to sedimentation rate, Gieskes, 1981). To some extent this may be the result of the Pliocene-
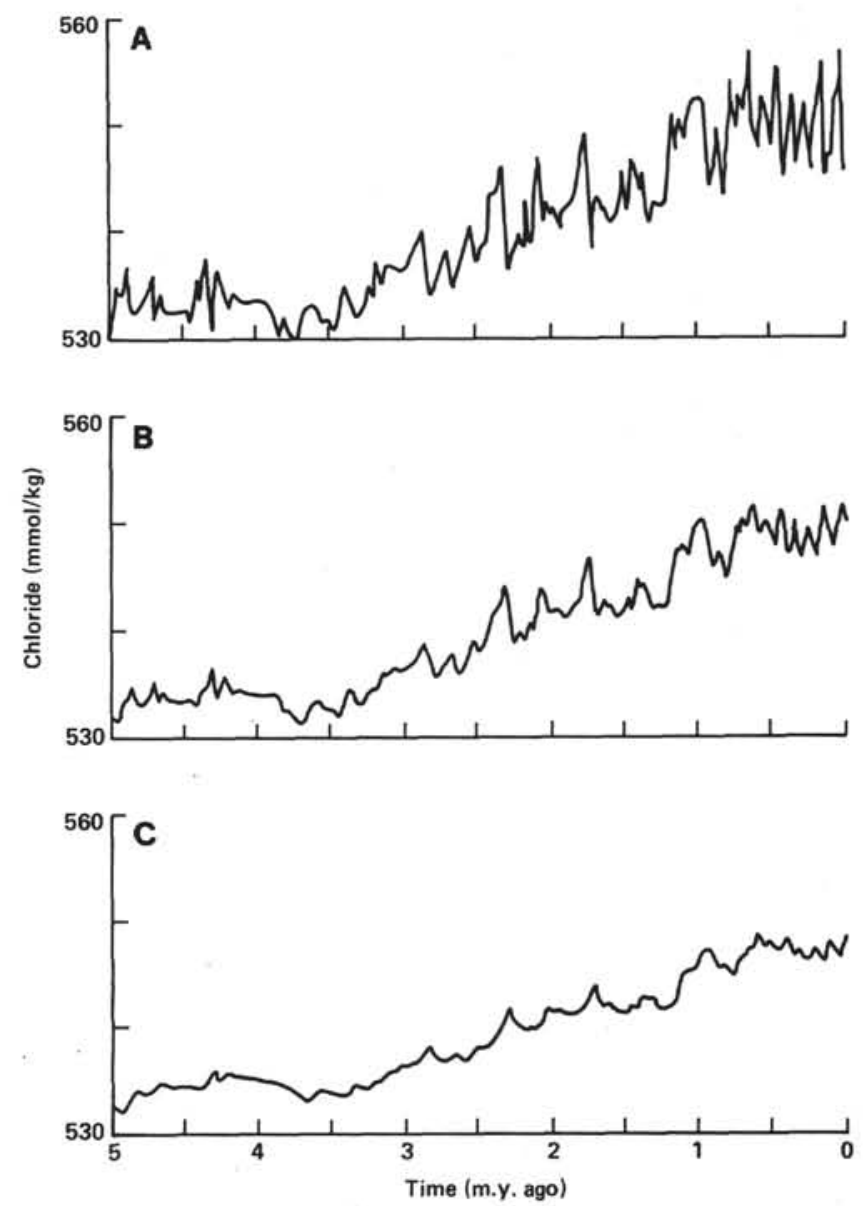

Figure 7. Model chloride curves versus time at (A) $10 \mathrm{~m}$, (B) $30 \mathrm{~m}$, and (C) $60 \mathrm{~m}$ sub-bottom depth computed as described in text. Note that the magnitude of the shift depends on the assumption made as to sea level. See caption of Figure 6.

Pleistocene increase in sedimentation rate. Second, the $\mathrm{Sr} / \mathrm{Ca}$ ratio achieved is much below the equilibrium ratio of $\sim 5 \times$ seawater for these pore waters (Baker et al., 1982).

\section{Lithium}

Gieskes (1981) noted an association of Li enrichment with $\mathrm{Si}$ enrichment and has commented on the contrasting chemistries of $\mathrm{Li}$ and $\mathrm{K}$. The data for Sites 578-580 generally agree with these ideas. Site 577 , with predominantly carbonate sediment, shows no significant $\mathrm{Si}$ enrichment and slightly decreasing $\mathrm{Li}$ values. Site $576 \mathrm{ex}-$ hibits a much different pattern. $\mathrm{Si}$ is significantly elevated in the upper sediment with little influence on $\mathrm{Li}$. As depth increases, $\mathrm{Si}$ decreases while Li increases. Drilling was terminated at a chert horizon, perhaps supporting a downward flux of $\mathrm{Si}$ and exclusion of $\mathrm{Li}$ as silicification proceeds.

\section{ACKNOWLEDGMENTS}

I thank Ms. Barbara Paul and Mr. Ron Citterman for assistance in the laboratory. Dr. Peter Grootes and Dr. Paul Quay of the Quaternary Isotope Laboratory, University of Washington facilitated the oxygen-isotope determinations. Ms. Trudy Rasp and Ms. Shirley. Patterson prepared versions of the manuscript. This manuscript was reviewed by James Lawrence and Joris Gieskes. This research was 


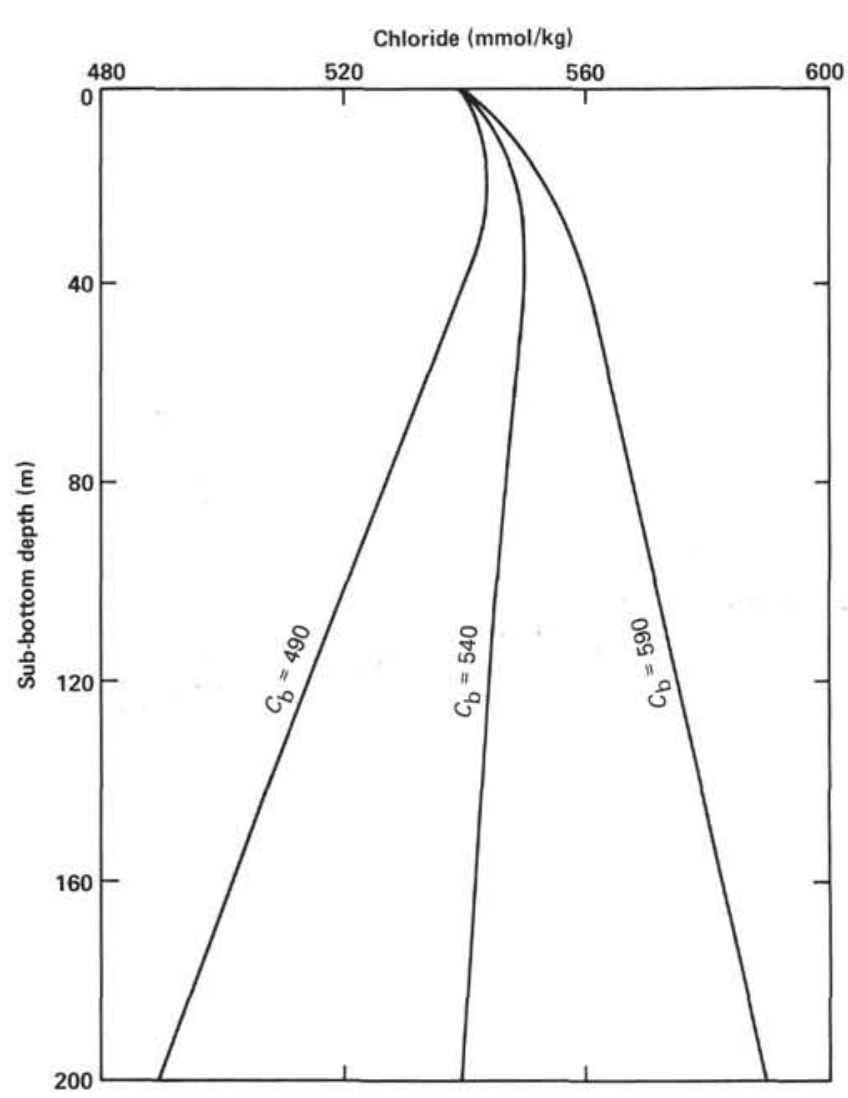

Figure 8. Model chloride curves versus sub-bottom depth at the present time for three different values of $c_{\mathrm{b}}$. Note that the magnitude of the shift depends on the assumption made as to sea level. See caption of Figure 6.

supported by Sandia National Laboratories (Contracts 26-6612 and 47-5696). This is University of Washington School of Oceanography Contribution No. 1427.

\section{REFERENCES}

Anderson, R. N., Hobart, M. A., and Langseth, M. G., 1979. Geothermal convection through oceanic crust and sediments in the Indian Ocean. Science, 204:828-832.

Baker, P. A., Gieskes, J. M., and Elderfield, H., 1982. The distribution of $\mathrm{Sr}^{2+}$ during diagensis of pelagic carbonate rocks-isotopic, chemical, and experimental evidence. J. Sediment. Petrol., 52: 71-82.

Boyle, E. A., 1983. Manganese carbonate overgrowth on foraminifera tests. Geochim. Coschim. Acta, 47:1815-1819.

Emerson, S., Fischer, K., Reimers, C., and Heggie, D., 1985. Organic carbon dynamics and preservation in deep sea sediments. Deep Sea Res., 32:1-22.

Epstein, S., and Mayeda, T., 1953. Variations in the ${ }^{18} \mathrm{O}$ content of water from natural sources. Geochim. Cosmochim. Acta, 4: 213-224.
Froelich, P. N., Klinkhammer, G. P., Bender, M. L., Luedtke, N. A., Heath, G. R., Cullen, D., Dauphin, P., Hammond, D., and Hartman, B., 1979. Early oxidation of organic matter in pelagic sediments of the eastern equatorial Atlantic: suboxic diagenesis. Geochim. Cosmochim. Acta, 43:1075-1090.

Gardner, W. S., Wynne, D. S., and Dunstan, W. M., 1976. Simplified procedure for the manual analysis of nitrate in seawater. Mar. Chem., 5:393-396.

Gieskes, J. M., 1974. Interstitial water studies, Leg 25. In Simpson, E. S. W., Schlich R., et al., Init. Repts. DSDP, 25: Washington (U.S. Govt. Printing Office), 361-394.

1981. Deep-sea drilling interstitial water studies: implications for chemical alteration of the oceanic crust, layers I and II. Soc. Econ. Paleontol. Mineral. Spec. Publ., 32:149-167.

Gieskes, J. M., and Lawrence, J. R., 1976. Interstitial water studies, Leg 35. In Hollister, C. D., Craddock, C., et al., Init. Repts. $D S D P, 35$ : Washington (U.S. Govt. Printing Office), 407-424.

1981. Alteration of volcanic matter in deep sea sediments: evidence from the chemical composition of deep sea drilling cores. Geochim. Cosmochim. Acta, 45:1687-1703.

Imbrie, J., Hays, J. D., McIntyre, A., Mix, C., Morley, J. J., Martinson, D. G., Pisias, N. G., Prell, W. L., and Leinen, M., 1984. The orbital theory of Pleistocene climate: support from a revised chronology of the marine $\delta^{18} \mathrm{O}$ record. In Berger A., Imbrie, J., Hays, J., Kukla, G., and Saltzman, B. (Eds.), Milankovitch and Climate: Dordrecht (Reidel).

Jahnke, R., Emerson, S., and Murray, J. W., 1982. A model of oxygen reduction, denitrification, and organic matter mineralization in marine sediments. Limnol. Oceanogr., 27:610-623.

Lawrence, J. R., and Gieskes, J. M., 1981. Constraints on water transport and alteration in the oceanic crust from the isotopic composition of pore water. J. Geophys. Res., 86:7924-7934.

McDuff, R. E., 1978. Conservative behavior of calcium and magnesium in the interstitial waters of marine sediments: identification and interpretation [Ph.D. dissert.]. University of California, San Diego.

1981. Major cation gradients in DSDP interstitial waters: the role of diffusive exchange between seawater and upper oceanic crust. Geochim. Cosmochim. Acta, 45:1705-1713.

McDuff, R. E., and Gieskes, J. M., 1976. Calcium and magnesium profiles in DSDP interstitial waters: diffusion or reaction. Earth Planet. Sci. Lett., 33:1-10.

Mann, R., and Gieskes, J. M., 1975. Interstitial water studies, Leg 28. In Hayes, D. E., Frakes, L. A., et al., Init. Repts. DSDP, 28: Washington (U.S. Govt. Printing Office), 805-814.

Maris, C. R. P., and Bender, M. L., 1982. Upwelling of hydrothermal solutions through ridge flank sediments shown by pore water profiles. Science, 216:623-626.

Sayles, F. L., and Jenkins, W. J., 1982. Advection of pore fluids through sediments in the equatorial east Pacific. Science, 217:245-248.

Sayles, F. L., and Manheim, F. T., 1975. Interstitial solutions and diagenesis in deeply buried marine sediments: results from the Deep Sea Drilling Project. Geochim. Cosmochim. Acta, 39:102-127.

Shackleton, N. J., and Cita, M. B., 1979. Oxygen and carbon isotope stratigraphy of benthic foraminifers at Site 397: detailed history of climatic change during the late Neogene. In von Rad, U., Ryan, W. B. F., et al., Init. Repts. DSDP, 47, Pt 1: Washington (U.S. Govt. Printing Office), 433-445.

Date of Initial Receipt: 23 November 1983

Date of Acceptance: 13 July 1984 


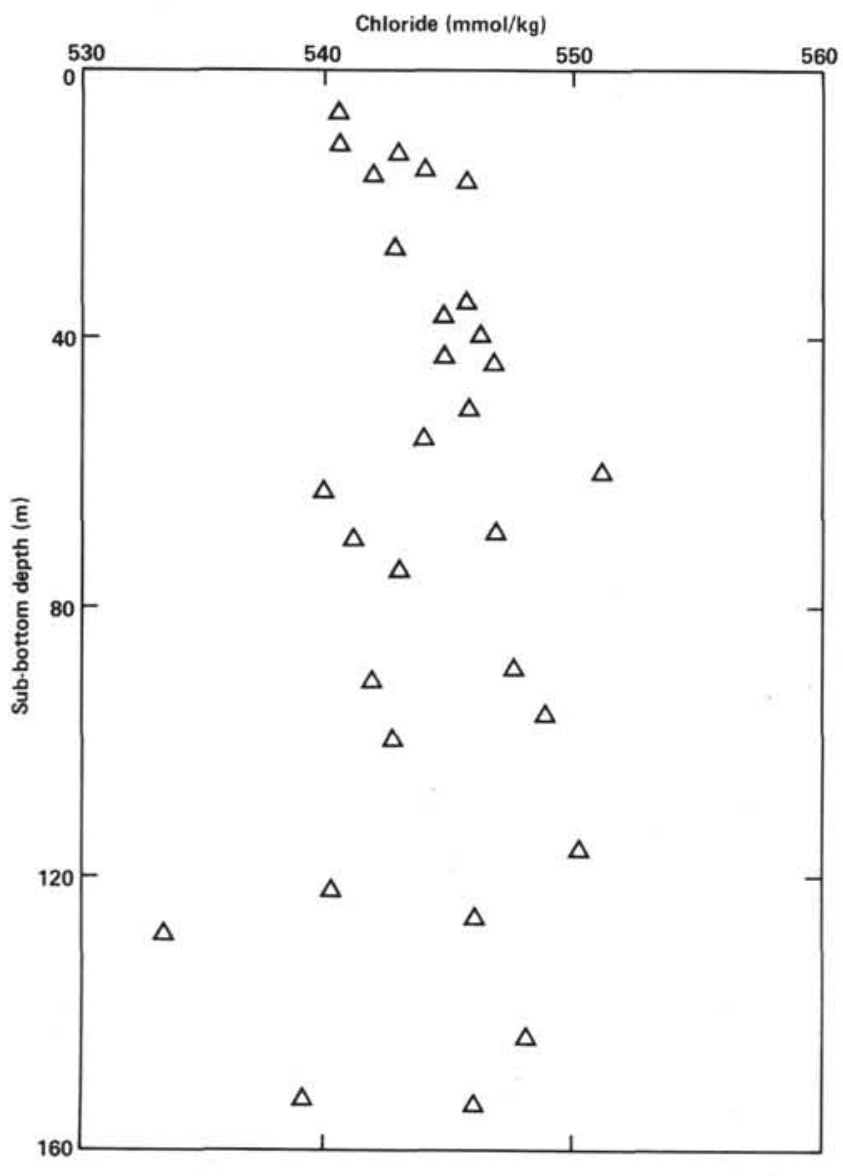

Figure 9. Composite of chloride versus sub-bottom depth for Leg 86 . In accord with the model curves (Fig. 8), chloride increases $\sim 1 \%$ by $40 \mathrm{~m}$ depth before assuming values controlled by diffusion from below. Note that the concentration scale is considerably expanded as compared to Figure 8 .

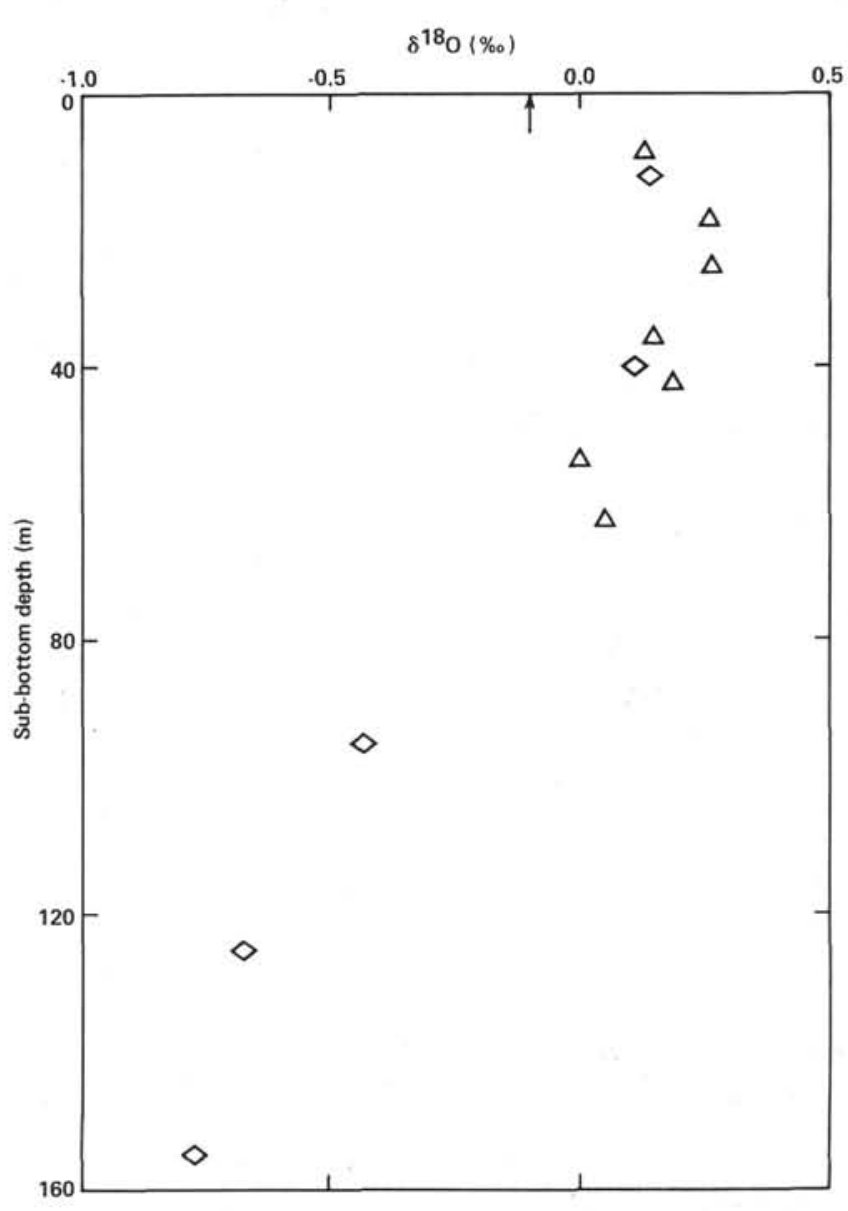

Figure $10 . \delta^{18} \mathrm{O}$ versus sub-bottom depth for Sites 576 and 578 . Symbols: diamond $=$ Site 578, triangle $=$ Site 576. Arrow indicates bottom-water value. 


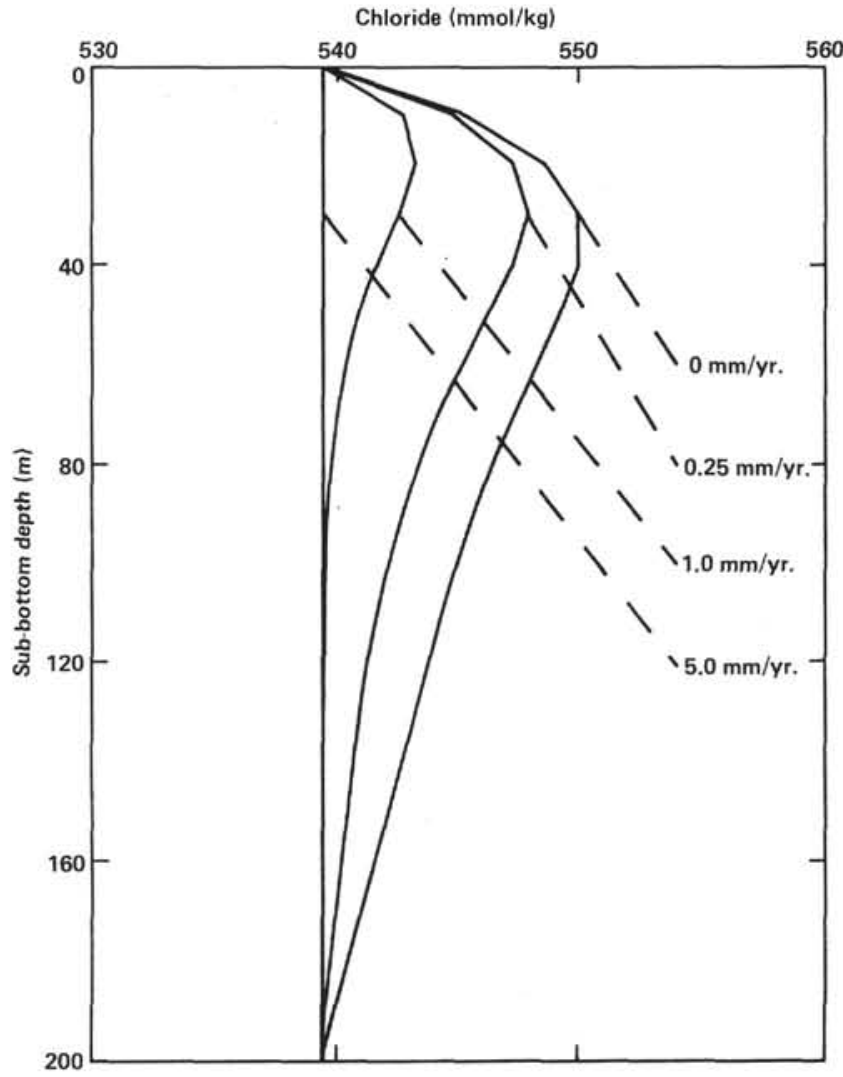

Figure 11. Model curves of chloride versus sub-bottom depth at the present time for different values of upward advection rate. Velocities of the order $1.0 \mathrm{~mm} / \mathrm{yr}$. shift the maximum upward and reduce its magnitude. Higher velocities eliminate the signal entirely.

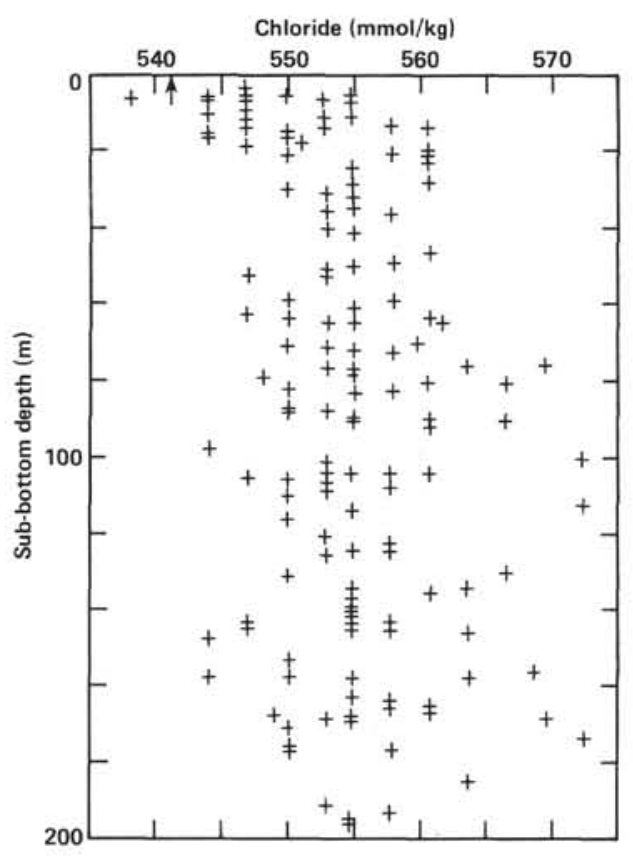

A

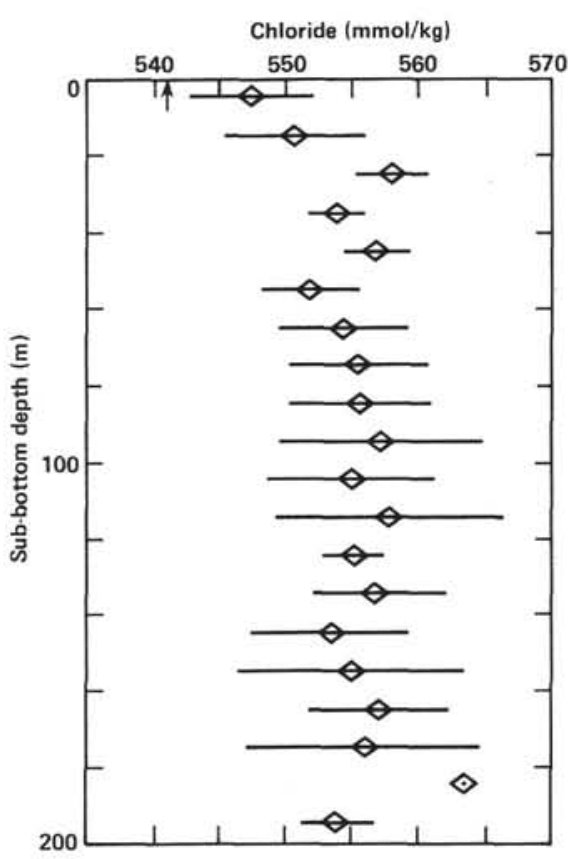

B

Figure 12. Composite of chloride versus sub-bottom depth for DSDP sites summarized by McDuff (1981) (A) Raw data. (B) Means and standard deviations in 10-m depth intervals. Note especially the tight standard deviation at about $40 \mathrm{~m}$ depth and that no value falls below $550 \mathrm{mmol} / \mathrm{kg}$ between 20 and 50 $\mathrm{m}$ depth. Typical deep waters have $\mathrm{Cl}=541 \mathrm{mmol} / \mathrm{kg}$ (arrow). 


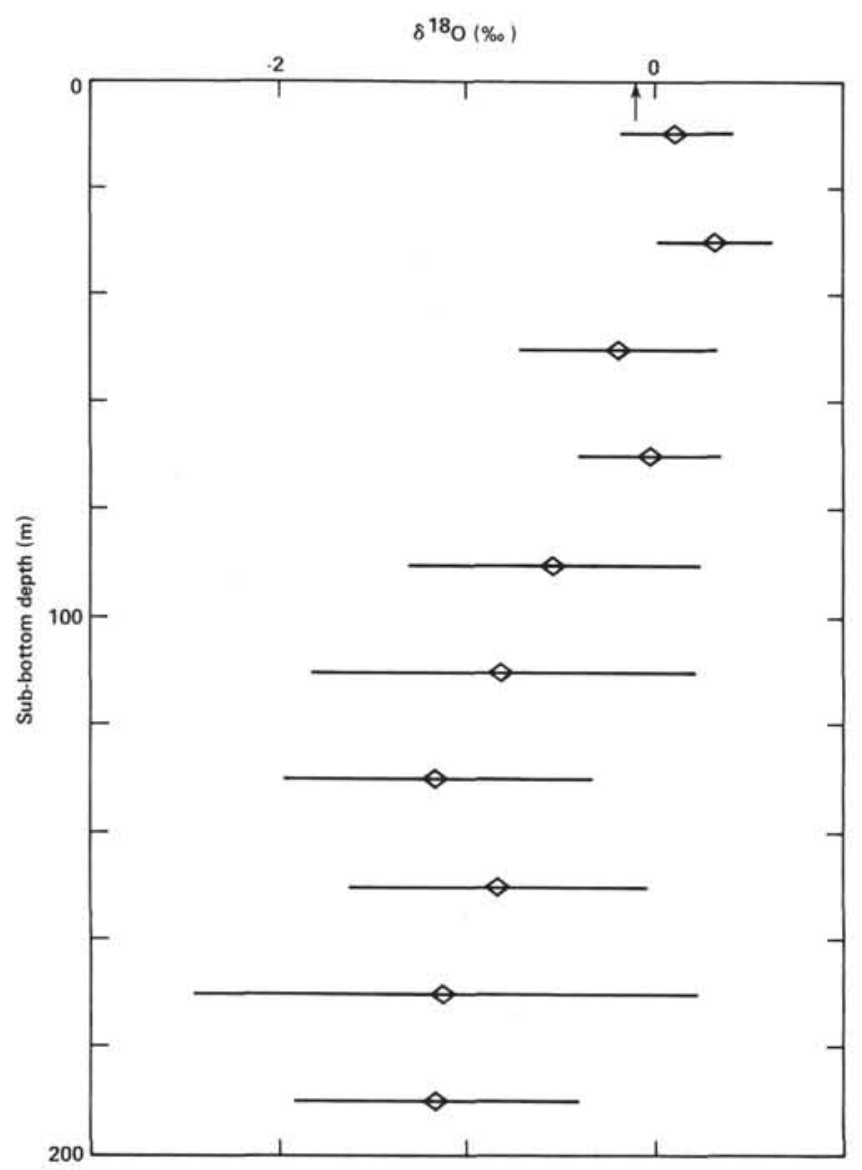

Figure 13. Composite of $\delta^{18} \mathrm{O}$ versus sub-bottom depth for DSDP sites summarized by Lawrence and Gieskes (1981) and expressed as means and standard deviations in $20-\mathrm{m}$ depth intervals. Note the slight maximum at $20-40 \mathrm{~m}$ depth. Arrow indicates bottom-water value.
Table 4. Parameters relating to $\mathrm{Ca}$ and $\mathrm{Mg}$, Leg 86 .

\begin{tabular}{cccccc}
\hline & $\begin{array}{c}\text { Deepest } \\
\text { sample } \\
\text { Site }\end{array}$ & $\begin{array}{c}\Delta \mathrm{Ca} \\
(\mathrm{mmol} / \mathrm{kg})\end{array}$ & $\begin{array}{c}\Delta \mathrm{Mg} \\
(\mathrm{mmol} / \mathrm{kg})\end{array}$ & $-\Delta \mathrm{Ca} / \Delta \mathrm{Mg}$ & $\begin{array}{c}\mathrm{Ca} \text { gradient } \\
(\mathrm{mmol} / \mathrm{kg} / \mathrm{m})\end{array}$ \\
\hline 576 & 62 & 0 & 0 & - & 0 \\
577 & 121 & 0 & 0 & - & 0 \\
578 & 152 & +5 & -5 & 1.0 & 0.03 \\
579 & 143 & +2 & -5 & 0.4 & 0.02 \\
580 & 153 & +2 & -7 & 0.3 & 0.01 \\
\hline
\end{tabular}

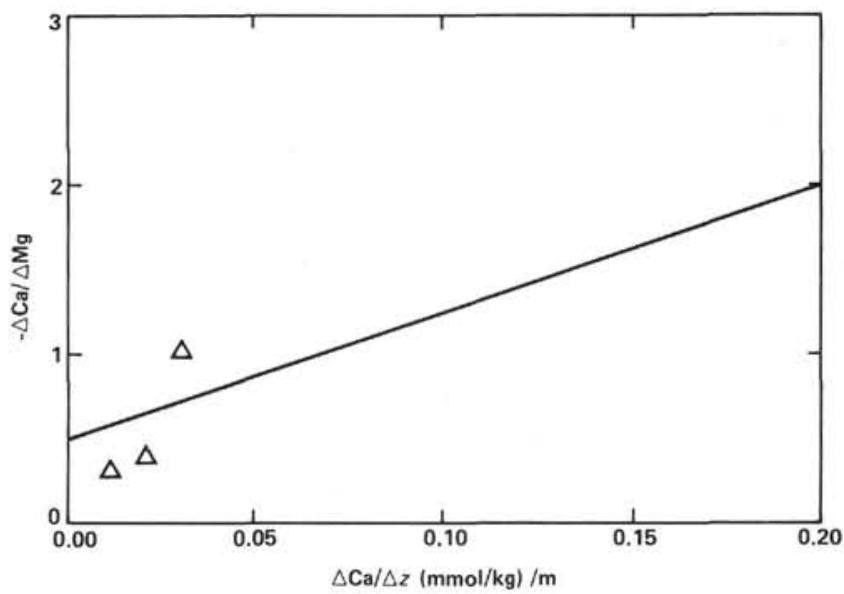

Figure 14. $-\Delta \mathrm{Ca} / \Delta \mathrm{Mg}$ versus $\Delta \mathrm{Ca} / \Delta z$. Points are for sites with gradients, see Table 4. Line is trend for DSDP Legs 1-53 summarized by McDuff (1981) (sites with gradients, $\mathrm{Ca}$ and $\mathrm{Mg}$ linearly correlated). 